\title{
FINANCIAL ASPECT OF USING THE ASPHALT GRANULATE IN MIXTURES DESIGNED FOR ROAD SUBSTRUCTURES
}

Ewa Ołdakowska, PhD (ORCID: 0000-0002-5437-2470) - Bialystok University of Technology Jakub Ołdakowski, student - Bialystok University of Technology

Correspondence address:

Bialystok University of Technology

Wiejska 45 Street, 15-351 Bialystok, Poland

e-mail: e.oldakowska@pb.edu.pl

ABSTRACT: Asphalt granulate is a valuable building material suitable for the production of asphalt mixtures. Its use in modern road building is profitable not only for environmental reasons but also because of the economic aspect of saving natural aggregates and asphalt and saving road pavement construction costs. The purpose of the cost analyses was to determine the financial benefits resulting from using the asphalt granulate in asphalt mixtures. The cost calculations concerned the basic components of asphalt mixtures and the costs of constructing the pavement structure layer for which the mixtures had been intended. The analyses covered asphalt mixtures of asphalt concrete type AC 22P with different content of asphalt granulate purchased at different prices, intended for road pavement substructure layers loaded with traffic of KR3 and KR4 categories.

KEYWORDS: asphalt granulate, cost analysis, recycling, road substructure, sustainable development 


\section{Introduction}

The recycling of asphalt pavements is highly desirable due to their ecological and economic aspects. The reuse of asphalt waste as an additive to asphalt mixtures began in the United States as early as 1915. However, it was only in the 1970s that there was a renewed interest in waste produced from milling the old pavements as a result of the oil crisis, which had resulted in a significant increase of prices of various materials, including bitumen (Application..., 2014, Epps, 1994, West, 2010). Not only the United States of America began the large-scale use the asphalt granulate to produce the asphalt mixtures, but also Western European countries. However, its content in the mixtures did not exceed $20 \%$ back then. Currently, the countries leading in the road construction sector are striving for maximum use of asphalt granulate to produce new mineral and asphalt mineral mixtures (Olard et al., 2008, Valdés et al., 2011, Aurangzeb et al., 2014). Its amount depends on the granulate dosing method during the production of mixtures. In Poland, according to the Appendix to Decree no. 54 of General Director of National Roads and Motorways from 8.11.2014 „Asphalt pavements on national roads” (WT-2 2014), the addition of up to $20 \%$ (addition of asphalt granulate to the paving plant mixer without preheating - "cold method") or 30\% ("hot method”, meaning the addition of asphalt granulate to the paving plant mixer with preheating) is permitted. However, the condition of use is the homogeneity of the granulate corresponding to the requirements and the presence of aggregate in the granulate, which size D must not be greater than size D for the mineral mixture included in the mineral and asphalt mixture. Taking into consideration the intended use of the mixtures, it should be noted that in most countries, using the additive is permitted in the substructure layers and in the binding layer, whereas in the surface layer using the granulate is not permitted or its use depends on the traffic load (Alenowicz, 2019, Bressi et al., 2015, Copeland, 2011, Olard \& Pouget, 2014). Despite the actions taken, Poland is a country where the use of asphalt waste to construct new or strengthening existing pavements is small and far from the standards of the leading countries in this respect (Bańkowski et al., 2016). This is confirmed by the annual EAPA (European AsphaltPavement Association) report (EAPA, 2012, EAPA, 2017), in which the last time it was found in 2012 with $4 \%$ use of granulate. The country of very significant material management is Finland. In 2017, out of 1,200,000 tonnes of asphalt waste obtained, 100\% was reused (EAPA, 2017). Likewise, in Japan, 99\% of all RAP (Reclaimed Asphalt Pavement) is reused in new pavement construction (West \& Coupland 2015). Also, in countries such as the USA (EAPA, 2017, Willis \& West, 2014), Slovakia, Hungary, and Belgium (EAPA, 2017), the problem of management of recycled 
materials is addressed rationally. The barriers for promoting the recycling of materials already identified by PIARC Technical Committee (Review..., 2007) are legislation, economics, lack of knowledge of road managers (investors). Therefore, the expected increase in using the granulate is a result of administrative activities, stable and long-term policy, the development of research and educational activities (Alenowicz, 2019). In recent years in Poland, there have been no clear provisions in the regulations governing the use of asphalt granulate and some provisions in the technical specifications for road investments, sometimes even limiting using the asphalt granulate in asphalt mixtures (Wasilewska et al., 2015). However, an increasing number of newly built and renovated roads has contributed to the adjustment of regulations allowing for reuse of "waste material”, which, as indicated by studies conducted in many research centres (Bańkowski et al., 2018, Edil, 2018, Ma et al., 2011, Mangiafico et al., 2013, Nokkaew, 2018, Plati \& Cliatt, 2019, Reza Pouranian \&Shishehbor, 2019, Sangiorgi et al., 2017, Tabaković et al., 2010, Xiao et al., 2018), may be a very valuable material for reuse.

Such reuse has many financial and environmental benefits (Horvath, 2003, Lee et al., 2010, Jamshidi \& White 2020):

- reduction of dumps in landfills, and thus reduction of storage costs (for storage of asphalt waste in Poland an environmental fee is charged (Obwieszczenie ..., 2020), which in 2021 is to 20.82 PLN/Mg; 1 PLN $=0.26$ USD),

- reduction of road pavement construction costs due to lower demand for new material,

- reduction of transport costs if the material is reused on-site,

- reduction in environmental costs (Zarei et al., 2020) connected with recovery and preparation of primary material and production of asphalt mixtures in the world (production absorbs large amount of non-renewable natural resources and is responsible for tens of millions of tons of $\mathrm{CO}_{2}$, which record concentration in the atmosphere, on the weekend of 12-13 May 2019, recorded and confirmed by the scientistsfrom the Observatory Mauna Loa in Hawaii, amounted to 415.26 ppm (TVNMETEO).

The use of asphalt granules in asphalt mixtures incorporated into the structure of new pavements is a direct saving of natural aggregates and bitumen (materials from non-renewable sources).It also means direct savings on the costs of road pavement construction, which depend on the prices and availability of the materials used.Furthermore, asphalt granulate in asphalt mixtures built into the structure of new pavements is also a response to the reduction of environmental pollution. The paper aims to determine the level of savings resulting from using the "valuable waste material” (which is an asphalt granulate) in the asphalt mixtures. 


\section{Subject and method of calculation}

\section{Subject of analysis}

In order to determine the financial benefits resulting from using the asphalt granulate in asphalt mixtures, the cost analyses have been carried out, including the calculation of costs of basic components of asphalt mixtures and the valuation of costs of constructing the pavement layer for which the mixtures were intended. To assess the costs, the asphalt mixtures of asphalt concrete of type AC $22 \mathrm{P}$ were used, intended for substructure layers of road pavement loaded with traffic of categories KR3 and KR4. The asphalt mixtures have been designed in accordance with (WT-2 2014). They were made from the mixture of aggregates (limestone dust, crushed and washed sand $0 / 2$, broken sand $0 / 2$, grit $2 / 8$; grit $8 / 16$; grit $11 / 16$, grit $16 / 22$ ) of constant granulometric composition and asphalt granulate in the amount of $0 \%$ (reference mixture), $10 \%, 15 \%$, and $20 \%$, meeting the requirements (WT-2 2014, PN-EN 13108-8:2016). Road bitumen 35/50 was used for the asphalt mixtures. The list of compositions, averaged over several designed asphalt mixtures, is presented in table 1.

Table 1. List of compositions (share in \%) of asphalt mixtures AC 22 P 35/50 KR 3-4 containing various amounts of asphalt granulate

\begin{tabular}{lllll}
\hline \multirow{2}{*}{ Type of material } & \multicolumn{4}{l}{$\begin{array}{l}\text { Composition (share in \%) of asphalt mixtures AC 22 P 35/50 KR 3-4 } \\
\text { with use of granulate in the amount of }\end{array}$} \\
\cline { 2 - 5 } & $\mathbf{0} \%$ & $10 \%$ & $15 \%$ & $20 \%$ \\
\hline Bitumen & 4.20 & 3.60 & 3.30 & 3.00 \\
Aggregate & 95.80 & 86.70 & 82.20 & 77.60 \\
Granulate & - & 9.70 & 14.50 & 19.40 \\
Total & 100.00 & 100.00 & 100.00 & 100.00 \\
\hline
\end{tabular}

Source: author's work.

\section{Calculation method}

The assessment of costs of manufacturing the asphalt mixtures AC $22 \mathrm{P}$ 35/50 KR 3-4 of different granulate content and the assessment of costs of manufacturing $1 \mathrm{~m}^{2}$ of substructure layer were carried out based on a detailed calculation method (according to the commonly accepted cost calculation principles) and with use of prices and cost factors included in the monthly information (Informacja miesięczna..., 2021) and quarterly information (Informacja o stawkach..., 2021 and Informacja o cenach..., 2021) of "Seko- 
cenbud" publishing house. The granulate price was determined based on sales offers (unit prices ranged from PLN 45 to 75 per Mg).

\section{Analysed data}

In order to determine the costs of manufacturing the asphalt mixtures of different granulate content, three formulations of mixtures in 4 price variants (differing in the unit price of granulate) have been considered: variant I - PLN 45 per Mg, variant II - PLN 55 per Mg, variant III - PLN 65 per Mg, variant IV - PLN 75 per Mg). Prices of 1 ton of waste material do not include the purchase costs and the external transport costs, which should be calculated individually according to the actual distance of deliveries and construction site organisation. The unit prices of other components of mixtures AC 22 P 35/50 KR 3-4 are listed in table 2.

Table 2. List of unit prices (PLN/t) of materials used for the production of asphalt mixtures AC 22 P 35/50 KR 3-4 containing various amounts of asphalt granulate

\begin{tabular}{ll}
\hline Material & Price [PLN/t] \\
\hline Limestone dust & 94.04 \\
Crushed and washed sand 0/2 & 30.60 \\
Broken sand 0/2 & 54.51 \\
Grit 2/8 & 104.81 \\
Grit 8/16 & 87.80 \\
Grit 11/16 & 87.80 \\
Grit 16/22 & 89.72 \\
Bitumen 35/50 & 1750.00 \\
\hline
\end{tabular}

Source: author's work.

Table 3. List of unit prices of labour and work of construction equipment used for the realisation of substructure made from asphalt mixtures AC 22 P 35/50 KR 3-4 containing various amounts of asphalt granulate

\begin{tabular}{ll}
\hline Specification & Price \\
\hline Labour & $21.10[$ PLN/man-hour] \\
Self-propelled static roller 10 t & $87.73[$ PLN/machine-hour] \\
Self-propelled static roller 15 t & $97.13[$ PLN/machine-hour] \\
Bituminous mass spreader & $204.23[$ PLN/machine-hour] \\
\hline
\end{tabular}

Source: author's work.

In order to determine the costs to be incurred for the realisation of $1 \mathrm{~m}^{2}$ of substructure layer made from mixtures with various granulate contents, the price assumptions for labour and work of construction equipment were 
made in accordance with (Informacja o stawkach..., 2021 and Informacja o cenach..., 2021) and shown in table 3.

The cost estimate price for realisation of the substructure layers was determined using formula (1) (Kowalczyk and Zabielski, 2011):

$$
C_{k}=\sum(L \times n \times c)+K_{p}+Z+P_{v}
$$

where:

$C_{k}$ - costestimate value,

$L$ - numberof take-off units,

$n-$ unitexpenditures,

$c$ - unitprices of production factors,

$K_{p}$ - indirectcosts for the whole range of works,

$Z$ - calculationprofit for the whole works,

$P_{v}$ - value-added tax.

The unit expenditures were determined according to the Outlays In-kind Catalogue 2-31 (Katalog... KNR 2-31, 1997). The overhead indices for engineering works, which include construction works: road works (including access roads, parking lots, and garbage yards included in the construction equipment), track works, bridge works, works in the range of power networks and connections, telecommunication, water, sewage, gas, and heating networks, sewage treatment plant and water treatment plants works, as well as greenery, hydrotechnical, water and melioration, and well works, etc., have been based upon (Informacja miesięczna..., 2021).

\section{Results and discussion}

The costs of basic components needed to realiseasphalt mixtures of different granulate content are presented in tables 4, 5, 6, and 7. Table 4 (variant I) contains cost data estimated upon the basis of calculations, assuming that the granulate costs PLN 45 per Mg. The results of price calculations included in tables 5, 6, and 7 (variants II, III, and IV, respectively) are the values determined on the assumption that PLN 55, PLN 65, and PLN 75 will have to be paid for 1 ton of granulate.

The total amount, including the values of all components of the mineral and asphalt mixture AC 22 P 35/50 KR 3-4 without the addition of asphalt granulate, is PLN 149.88. The most expensive component in the analysed mixture is bitumen, for which, at its current prices, one must pay PLN 73.50, which accounts for $49.04 \%$ of the total cost. The cost of aggregate is the value of PLN 76.38, i.e. $50.96 \%$ of total outlays. 
Table 4. List of costs [in PLN] of the basic components of asphalt mixtures AC 22 P 35/50 KR 3-4 containing various amounts of asphalt granulate, assuming that the granulate costs PLN 45/ton

\begin{tabular}{lllll}
\hline \multirow{2}{*}{ Type of material } & \multicolumn{4}{l}{ Costs [in PLN] of the basic components of asphalt mixtures } \\
& \multicolumn{4}{l}{ AC 22 P 35/50 KR 3-4 with use of granulate in the amount of } \\
\cline { 2 - 5 } & $\mathbf{0} \%$ & $\mathbf{1 0 \%}$ & $\mathbf{1 5 \%}$ & $\mathbf{2 0 \%}$ \\
\hline Bitumen & 73.50 & 63.00 & 57.75 & 52.50 \\
Aggregate & 76.38 & 70.49 & 67.53 & 64.49 \\
Granulate & - & 4.37 & 6.53 & 8.73 \\
Total & 149.88 & 137.86 & 131.81 & 125.72 \\
\hline
\end{tabular}

Source: author's work.

Table 4, apart from the costs of components of the reference mixture AC 22 P 35/50 KR 3-4, also presents the costs of components of the mixtures with $10 \%, 15 \%$ and $20 \%$ of asphalt granulate content, which costs PLN 45 per ton. Expenditures on materials in case of a mineral and asphalt mixture with $10 \%$ addition of asphalt granulate equal to PLN 137.86, and at the same time, the value is lower by PLN 12.03 (8.02\%) than the price of the reference mixture. The expenditures to be spent on materials necessary to make a mixture with $15 \%$ of granulate are PLN 131.81, which is the value lower by PLN 18.08 in relation to the standard mixture. In case of a mineral and asphalt mixture with $20 \%$ share of granulate, the price decreased by PLN 24.16 and amounted to PLN 125.72.

In order to determine the impact of the addition of asphalt granulate purchased at the price of PLN 55 per ton (table 5) on the costs of asphalt mixtures for the substructure layer, an analogous analysis was performed as in the case of a variant I, using the formulas of mixtures presented in table 1.

Table 5. List of costs [in PLN] of the basic components of asphalt mixtures AC 22 P 35/50 KR 3-4 containing various amounts of asphalt granulate, assuming that the granulate costs PLN 55/ton

\begin{tabular}{lllll}
\hline \multirow{2}{*}{ Type of material } & \multicolumn{4}{l}{$\begin{array}{l}\text { Costs }[\text { in PLN] of the basic components of asphalt mixtures AC 22 P 35/50 KR } \\
\text { 3-4 containing various amounts of asphalt granulate of }\end{array}$} \\
\cline { 2 - 5 } & $\mathbf{0} \%$ & $\mathbf{1 0 \%}$ & $\mathbf{1 5 \%}$ & $\mathbf{2 0 \%}$ \\
\hline Bitumen & 73.50 & 63.00 & 57.75 & 52.50 \\
Aggregate & 76.38 & 70.49 & 67.53 & 64.49 \\
Granulate & - & 5.34 & 7.98 & 10.67 \\
Total & 149.88 & 138.83 & 133.26 & 127.66 \\
\hline
\end{tabular}

Source: author's work. 
The costs of components needed to make 1 ton of mineral and asphalt mixture AC $22 \mathrm{P}$ with the addition of asphalt granulate (costing PLN 55 per $\mathrm{Mg}$ ) in the amount of $10 \%$ are PLN 138.83. It is less by PLN 11.06 than the mixture without the addition of asphalt granulate. The higher amount of waste material in the composition of mixtures means lower total prices of those mixtures - respectively PLN 133.26 in case of $15 \%$ content of valuable waste material and PLN 127.66 in relation to $20 \%$ of its amount.

Table 6 presents a list of costs of analysed mixtures assuming that the granulate will be purchased at the price of PLN 65 per Mg. Each of the mixtures is characterised by a different price due to the different granulatecontent, which also affects the correction of the binder and aggregatequantity.

Table 6. List of costs [in PLN] of the basic components of asphalt mixtures AC 22 P 35/50 KR 3-4 containing various amounts of asphalt granulate, assuming that the granulate costs PLN 65/ton

\begin{tabular}{lllll}
\hline \multirow{2}{*}{ Type of material } & \multicolumn{4}{l}{ Costs [in PLN] of the basic components of asphalt mixtures } \\
& \multicolumn{4}{l}{ AC 22 P 35/50 KR 3-4 with use of granulate in the amount of } \\
\cline { 2 - 5 } & $\mathbf{0} \%$ & $10 \%$ & $15 \%$ & $20 \%$ \\
\hline Bitumen & 73.50 & 63.00 & 57.75 & 52.50 \\
Aggregate & 76.38 & 70.49 & 67.53 & 64.49 \\
Granulate & - & 6.31 & 9.43 & 12.61 \\
Total & 149.88 & 139.80 & 134.71 & 129.60 \\
\hline
\end{tabular}

Source: author's work.

A list of costs (table 6) of the basic components of asphalt mixtures with different contents of asphalt waste shows its clear impact on the total price of the mixture. One may notice that the more material created after milling old pavements in the mixture, the lower the price of the mixture and the smaller the amount of aggregate and asphalt. Thus, the addition of $10 \%$ of granulate made the total cost of all components lower by PLN 10.09compared to the cost of a mixture containing no asphalt granulate. The presence of $15 \%$ of the waste material caused the costs reduction to PLN 134.71, while the addition of $20 \%$ caused the price reduction to PLN 129.60 .

The values of materials used to prepareasphalt mixtures AC 22 P 35/50 KR 3-4 with $10 \%, 15 \%$, and $20 \%$ of the quantity of asphalt granulate purchased at the price of PLN 75 per ton are presented in table 7.

The last analysed variant is a variant in which the use of granulate purchased at the price of PLN 75 per ton was considered, which means that it will be cheaper only by $28 \%$ than the most expensive component of the aggregate mixture, and at the same time, it will be more expensive by more 
than $60 \%$ compared to the price assumed in variant I ("the cheapest"). Similarly to the considered variants, No. I, II, and III, the asphalt granulate in the amount of $0 \%$ (standard mixture), $10 \%, 15 \%$, and $20 \%$ were used.

Table 7. List of costs [in PLN] of the basic components of asphalt mixtures AC 22 P 35/50 KR 3-4 containing various amounts of asphalt granulate, assuming that the granulate costs PLN 75/ton

\begin{tabular}{lllll}
\hline \multirow{2}{*}{ Type of material } & \multicolumn{4}{l}{ Costs [in PLN] of the basic components of asphalt mixtures } \\
& \multicolumn{4}{l}{ AC 22 P 35/50 KR 3-4 with use of granulate in the amount of } \\
\cline { 2 - 5 } & $\mathbf{0} \%$ & $\mathbf{1 0 \%}$ & $\mathbf{1 5 \%}$ & $\mathbf{2 0 \%}$ \\
\hline Bitumen & 73.50 & 63.00 & 57.75 & 52.50 \\
Aggregate & 76.38 & 70.49 & 67.53 & 64.49 \\
Granulate & - & 7.28 & 10.88 & 14.55 \\
Total & 149.88 & 140.77 & 136.16 & 131.54 \\
\hline
\end{tabular}

Source: author's work.

As a result of the analysis of costs of the components needed for production of asphalt mixtures without and with asphalt granulate it has been found that the cost of the mixture decreased with the increase in the quantity of asphalt granulate in the mineral and asphalt mixture and irrespective of its purchase price (in the range considered). The percentage differences in relation to the prices of the reference mixture are shown in table 8.

Table 8. List of percentage differences of costs of the basic components of asphalt mixtures AC 22 P 35/50 KR 3-4 containing various amounts of asphalt granulate in relation to the reference mixture

\begin{tabular}{lllll}
\hline \multirow{2}{*}{\begin{tabular}{l} 
Mixture with granulate in $\begin{array}{l}\text { Granulate price } \\
\text { amount of }\end{array}$ \\
\cline { 2 - 5 }
\end{tabular}} & PLN 45 & PLN 55 & PLN 65 & PLN 75 \\
\hline $10 \%$ & $12.03 \%$ & $11.06 \%$ & $10.09 \%$ & $9.12 \%$ \\
$15 \%$ & $18.08 \%$ & $16.63 \%$ & $15.18 \%$ & $13.73 \%$ \\
$20 \%$ & $24.16 \%$ & $22.22 \%$ & $20.28 \%$ & $18.34 \%$ \\
\hline
\end{tabular}

Source: author's work.

The values presented in table 8 indicate that regardless of the amount of asphalt granulate additive and its purchase price (in the range considered), the use of the waste allows for significant savings. First of all, those are savings of natural aggregates and asphalt (granulate is a component "rich" in full value asphalt binder, it also reduces the amount of added aggregate), and 
secondly, those are savings in the cost of the mixtures themselves. The presence of $10 \%$ of the waste material is the cost of materials lower by over $9 \div 12 \%$ (in relation to the amounts set for the reference mixture), $15 \%$ of the content of milled old pavement is lower by $13 \div 18 \%$, while using the waste material in the amount of $20 \%$ is the cost reduced by $18 \div 24 \%$.

In order to compare the level of costs to be incurred for the realisation of $1 \mathrm{~m}^{2}$ of the typical substructure an analysis has been performed based upon the presented formulas of asphalt mixtures with different content of asphalt granulate. The differences in financial outlay for the construction of a typical $10 \mathrm{~cm}$ layer of the substructure result only from differences in unit prices of materials, as in each analysed case, the costs of labour and equipment, indirect costs, profit, and VAT are the same. The summary of costs of construction of $1 \mathrm{~m}^{2}$ of the substructure layer is presented in table 9 . In contrast, table 10 shows the percentage differences in relation to the construction costs of the substructure layer using the reference mixture.

Table 9. List of costs of the basic components of asphalt mixtures AC 22 P 35/50 KR 3-4 containing various amounts of asphalt granulate purchased at different prices

\begin{tabular}{lllll}
\hline \multirow{2}{*}{\begin{tabular}{l} 
Mixture with granulate in $\begin{array}{l}\text { Granulate price } \\
\text { amount of }\end{array}$ \\
\cline { 2 - 5 }
\end{tabular}} & PLN 45 & PLN 55 & PLN 65 & PLN 75 \\
\hline $0 \%$ & 58.52 & 58.52 & 58.52 & 58.52 \\
$10 \%$ & 55.06 & 55.34 & 55.62 & 55.90 \\
$15 \%$ & 53.32 & 53.74 & 54.16 & 54.57 \\
$20 \%$ & 51.57 & 52.13 & 52.69 & 53.25 \\
\hline
\end{tabular}

Source: author's work.

Table 10. List of percentage differences of costs of realisation of $1 \mathrm{~m}^{2}$ of the substructure from the asphalt mixturesAC 22 P 35/50 KR 3-4 containing various amounts of asphalt granulate in relation to realisation costs with the use of the reference mixture

\begin{tabular}{lllll}
\hline \multirow{2}{*}{\begin{tabular}{l} 
Mixture with granulate in $\begin{array}{l}\text { Granulate price } \\
\text { amount of }\end{array}$ \\
\cline { 2 - 5 }
\end{tabular}} & PLN 45 & PLN 55 & PLN 65 & PLN 75 \\
\hline $10 \%$ & $5.91 \%$ & $5.43 \%$ & $4.96 \%$ & $4.48 \%$ \\
$15 \%$ & $8.89 \%$ & $8.17 \%$ & $7.45 \%$ & $6.75 \%$ \\
$20 \%$ & $11.88 \%$ & $10.92 \%$ & $9.96 \%$ & $9.01 \%$ \\
\hline
\end{tabular}

Source: author's work.

Analysing the data presented in table 10, one should say that using the granulate (costs of labour and equipment, indirect costs, and contractor's 
profit do not change) causes reduction of realisation costs of $1 \mathrm{~m}^{2}$ of the substructure. The realisation of the layer from the mixture AC 22 P 35/50 KR 3-4 without the addition of asphalt granulate was characterised by a cost equal to PLN 58.52. In case of using $10 \%$ of asphalt granulate, the price of $1 \mathrm{~m}^{2}$ of substructure decreased to PLN 55.06, assuming that the granulate cost PLN 45 per ton, or to PLN 55.90 when PLN 75 was allocated for its purchase (1 ton). It makes a difference of $5.91 \%$ or $4.48 \%$, respectively, compared to the realisation of $1 \mathrm{~m}^{2}$ of the substructure from the reference mixture. The cost of constructing of the assumed substructure from a mixture in which the share of waste material amounted to $15 \%$, decreased by $6.75 \%$ for the "most expensive" price variant of the waste material. In the case of a mineral and asphalt mixture with the addition of $20 \%$ of granulate, the price decreased by $11.88 \%$ (assuming that it will cost PLN 45 per Mg) and amounted to PLN 51.57.

The decrease of realisation price per $1 \mathrm{~m}^{2}$ of road substructures may seem low, but considering the amounts connected with construction of many kilometres of roads, they may become very important in the total investment costs.

\section{Conclusions}

Using asphalt waste in the form of granulate in modern road construction is profitable not only for environmental reasons but also due to the economic aspect. The performed analysis clearly shows that with the increased amount of added asphalt granulate, the price of asphalt mixtures as well as the cost of their incorporation decrease. It results from lower demand for aggregate (desirable in the situation of increasingly limited access to high-quality rock raw material) and bitumen, the price of which is crucial for the production costs of mixtures. Another economic benefit associated with using the asphalt granulate for the production of new mixtures is the reduction in the number of waste dumps where the milled waste material is stored, for which fees must be paid. Using the asphalt granulate, apart from financial aspects, directly impacts environmental protection by solving the problem of granulate management and significantly reduces the use of natural non-renewable raw materials. The reuse of asphalt granulate as an additive to the asphalt mixtures gives measurable environmental and economic benefits without any negative impact on the final product, i.e. the mineral and asphalt mixture.

The cost analysis performed on the example of asphalt mixtures without asphalt granulate and with $10 \%, 15 \%, 20 \%$ of additive intended for road substructures, with presented assumptions, allowed to formulate the following conclusions: 
- With the increasing content of asphalt granulate in the constitution of a mineral and asphalt mixture, the costs of its components decrease. The cost of components needed to make a mineral and asphalt mixture AC 22 P 50/70 KR3-KR4 without the addition of asphalt granulate is PLN 149.88. The addition of asphalt granulate purchased at the price of PLN 45 and in quantities of $10 \%, 15 \%$, and $20 \%$ resulted in a decrease of price by PLN 12.03, PLN 18.08, and PLN 24.16, respectively, which in relation to the reference mixture constitutes respectively $8.02 \%, 12.06 \%$, and $16.12 \%$.

- The price of realisation of $1 \mathrm{~m}^{2}$ of $10 \mathrm{~cm}$ thick substructure layer made from mineral and asphalt mixture AC 22 P 5/50 KR3-KR4 without the addition of asphalt granulate was estimated at PLN 58.52. On the other hand, a layer made from the mixture with $10 \%$ of granulate content purchased at the price of PLN 75 per ton was valued at PLN 55.90 (less by PLN 2.62); a $10 \mathrm{~cm}$ thick substructure layer with $15 \%$ of waste material (also purchased at the price of PLN 75 per Mg) is the cost of PLN 54.57 (less by PLN 3.95). The presence of $20 \%$ of asphalt granulate in the mixture means the price lower by PLN 5.27 in relation to the reference mixture.

The decrease of realisation price per $1 \mathrm{~m}^{2}$ of road substructures may seem low. However,considering the amounts connected with construction of many kilometres of roads, they may become very important in the total investment costs.

\section{References}

Alenowicz, J., 2019. Uwarunkowania dotyczące zawartości granulatu asfaltowego $\mathrm{w}$ mieszankach mineralno-asfaltowych produkowanych na gorąco $\mathrm{w}$ otaczarkach cyklicznych. Magazyn Autostrady, 8-9, 30-37.

Application of Reclaimed Asphalt Pavement and Recycled Asphalt Shingles in HotMix Asphalt: National and International Perspectives on Current Practice, 2014. Transportation Research Board, Washington, D.C., USA.

Aurangzeb, Q., Al-Qadi, I. L., Ozer, H., Yang, R., 2014. Hybrid life cycle assessment for asphalt mixtures with high RAP content. Resource Conservation Recycling, 83, 77-86.

Bańkowski, W., Król, J., Gałązka, K., Liphardt, A., Horodecka, R., 2018. Design and verification of bituminous mixtures with the increased content of reclaimed asphalt pavement. IOP Conference Series: Materials Science and Engineering 2018, 356, 012009 DOI:10.1088/1757-899X/356/1/012009.

Bańkowski, W., Sybilski, D., Król, J., Kowalski, K., Radziszewski, P., Skorek, P., 2016. Wykorzystanie destruktu asfaltowego - konieczność i innowacja. Budownictwo i Architektura, 15 (1), 157-167, DOI: 10.24358/Bud-Arch_16_151_17.

Bressi, S., Cavalli, M. C., Partl, M. N., Tebaldi, G., Dumont, A. G., Poulikakos, L. D., 2015. Particle clustering phenomena in hot asphalt mixtures with high content of 
reclaimed asphalt pavements. Construction and Building Materials, 100, 201217.

Copeland, A., 2011. Reclaimed Asphalt Pavement in Asphalt Mixtures: State of the Practice. Federal Highway Administration, Office of Infrastructure Research and Development, Report No. FHWA-HRT-11-021, April 2011.

EAPA. 2012. https://eapa.org/wp-content/uploads/2018/07/2012.pdf

EAPA. 2017. https://eapa.org/wp-content/uploads/2019/08/Asphalt-in-figures_ 2017.pdf

Edil, T. A., 2018. Review of Recycled Aggregates (RAP and RCA) as Unbound Base Course Material for Sustainable Highway Construction. Congrès International de Géotechnique - Ouvrages - Structures. Springer. Singapur, 3-14.

Epps, J. A., 1994. Uses of Recycled Rubber Tires in Highways. Transportation Research Board; National Research Council, Washington, D.C., USA, Volume 198.

Horvath, A., 2003. Life - Cycle Environmental and Economic Assessment of Using Recycled Materials for Asphalt Pavements. Technical Report.

Informacja miesięczna o stawkach robocizny oraz o cenach wybranych robót, materiałów i sprzętu na dzień 30 kwietnia 2021 r., 2021. Sekocenbud - Błyskawica nr 4/2021, Ośrodek Wdrożeń Ekonomiczno-Organizacyjnych Budownictwa „Promocja”, Warszawa.

Informacja o stawkach robocizny kosztorysowej oraz cenach pracy sprzętu budowlanego w II kwartale 2021r., 2021. Sekocenbud - Zeszyt nr 23/2021, Ośrodek Wdrożeń Ekonomiczno-Organizacyjnych Budownictwa „Promocja”, Warszawa.

Informacja o cenach materiałów budowlanych w II kwartale 2021 r., 2021. Sekocenbud - Zeszyt nr 20/2021. Ośrodek Wdrożeń Ekonomiczno-Organizacyjnych Budownictwa „Promocja”, Warszawa.

Jamshidi, A. White, G., 2020. Evaluation of Performance and Challenges of Use of Waste Materials in Pavement Construction: A Critical Review. Applied Sciences, $10,226$.

Katalog Nakładów Rzeczowych KNR 2-31 - Nawierzchnie na drogach i ulicach. 1997. Ministerstwo Gospodarki Przestrzennej i Budownictwa.

Kowalczyk, Z., Zabielski, J., 2011. Kosztorysowanie i normowanie w budownictwie (Costing and standardization in construction), Wydawnictwa Szkolne i Pedagogiczne.

Lee, J.C., Edil, B. E., Tinjum, J. M., Benson, C.H., 2010. Quantitive assessment of environmental and economy benefits of recycled materials in highway construction. Journal of Transportation Research Board, 2158, 138-142.

Ma, B., Wang, H., Wei, D., 2011. Performance of RAP in the system of cold inplace recycling of asphalt pavement. Journal of Wuhan University of Technology-Mater. Sci. Ed, 26, 1211-1214.

Mangiafico, S., Benedetto, H., Di Sauzéat, C., Olard, F., Pouget, S., Dupriet, S., Planque, L., Van Rooijen, R., 2013. Statistical analysis of the influence of RAP and mix composition on viscoelastic and fatigue properties of asphalt mixes. Materials and Structures, DOI:10.1617/s11527-013-0225-z.

Nokkaew, K., 2018. Characterisation of recycled aggregate for use as base course material. International Journal of GEOMATE,15, 129-136.

Announcement of the Polish Minister of Climate of September 9, 2020 on the rates of environmental fees for 2021(M.P. 2020 poz. 961). 
Olard, F., Noan, C., Bonneau, D., Dupriet, S., Alvarez, C., 2008. Very high recycling rate $(>50 \%)$ in hot mix and warm mix asphalts for sustainable road construction. Proceedings of the 4th Eurasphalt and Eurobitume Congress. Copenhagen, Denmark.

Olard, F., Pouget, S., 2014. Current Status of RAP Application in France. Transportation Research Circular, Number E-C188, Transportation Research Board, 42-50.

Plati, Ch., Cliatt, B. A., 2019. Sustainability Perspective for Unbound Reclaimed Asphalt Pavement (RAP) as a Pavement Base Material, Sustainability, 11, 78.

PN-EN 13108-8: 2016 Bituminous mixtures - Material specifications - Part 8: Reclaimed asphalt.

Review of the Growth and Development of Recycling in Pavement Construction. 2007. PIARC TC 4.3.

Reza Pouranian, M., Shishehbor, M., 2019. Sustainability Assessment of Green Asphalt Mixtures. A Review Environments, 6, 73. doi:10.3390/environments6060073.

Sangiorgi, C., Tataranni, P., Simone, A., Vignali, V., Lantieri, C., Dondi, G., 2017. A laboratory and filed evaluation of Cold Recycled Mixture for base layer entirely made with Reclaimed Asphalt Pavement. Construction and Building Materials,138, 232-239.

Tabaković, A., Gibney, A., McNally, C., Gilchrist, M. G., 2010. Influence of Recycled Asphalt Pavement on Fatigue Performance of Asphalt Concrete Base Courses. Journal of Materials in Civil Engineering, 22 (6), 643-650.

TVNMETEO https://tvnmeteo.tvn24.pl/informacje-pogoda/nauka,2191/stezeniedwutlenku-wegla-w-atmosferze-nigdy-nie-bylo-tak-wysokie,290907,1,0.html.

Valdés, G., Pérez-Jiménez, F., Miró, R., Martínez, A., Botella, R., 2011. Experimental study of recycled asphalt mixtures with high percentages of reclaimed asphalt pavement (RAP). Construction and Building Materials, 25 (3), 1289-1297.

Wasilewska, M., Gardziejczyk, W., Plewa, A., Gierasimiuk, P., 2015. Wykorzystanie granulatu asfaltowego $\mathrm{w}$ podbudowie $\mathrm{z}$ betonu asfaltowego $\mathrm{w}$ nawierzchni drogowej (The use of asphalt granulate in the foundation of asphalt concrete in the road surface), Rocznik Ochrona Środowiska, 17, 973-997.

West, R., 2010. Reclaimed Asphalt Pavement Management: Best Practices; NCAT Draft Report; National Center for Asphalt Technology, Auburn, AL, USA.

West, R., Coupland, A., 2015. High RAP asphalt pavements: Japan practice-lessons learned. National Asphalt Pavement Association. Information Seri: Washington, DC, USA, 1-62.

Willis, J. R., West, R., 2014. Current Status of Reclaimed Asphalt Pavement Application in United States. Transportation Research Circular, Number E-C188, Transportation Research Board, 3-16.

Wymagania Techniczne WT - 2, 2014. Nawierzchnie asfaltowe na drogach krajowych (Asphalt pavements on national roads). Załącznik do zarządzenia Nr 54 Generalnego Dyrektora Dróg Krajowych i Autostrad z dnia 18.11.2014 r.

Xiao, F., Yao, S., Wang, J., Li, X., Amirkhanian, S., 2018. A literature review on cold recycling technology of asphalt pavement. Construction and Building Materials, 180, 579-604.

Zarei, M., Rahmani Z., Zahedi M., Nasrollahi M., 2020. Technical, Economic, and Environmental Investigation of the Effects of Rubber Powder Additive on Asphalt Mixtures. Journal of Transportation Engineering, Part B: Pavements, 146. 